\title{
香りがストレス状態に与える影響について
}

\author{
石戸谷豊昌，立川一義，荒木德博 \\ ポーラ化成工業株式会社研究所†
}

\section{Influence of a fragrance on stress}

\author{
Toyomasa Ishitoya, Kazuyoshi Tachikawa and Norihiro Araki \\ Pola R \& D Laboratories. $\dagger$
}

We studied the effect of a fragrance on stress, paying attention to the frequency fluctuation and cycle variances of $\alpha$-waves in EEG.

Four healthy subjects, ranging in age from 22 to 39 years, participated in the experiment. The EEG was recorded, keeping eyes shut and seated, from $\mathrm{Fz}, \mathrm{C} 3, \mathrm{C} 4, \mathrm{Cz}$, and $\mathrm{Oz}$ scalp location, reffered to linked ear lobes for 5 min during blank (rest), 2 min during stress (verbal task: backward recitation of 4 figures number), 5 min during fragrance preseentation (environmental fragrance " $D$ " citrus mint note developed by POLA. $\alpha$-wave component (8-13Hz) was extracted using a degital filter and the frequency fluctuation was analyzed using "Power spectrum" method. Cycle's variances ( $\mathrm{msec}$ ) were calculated every for 5 seconds and plotted.

The frequency fluctuation with a fragrance showed more $1 / \mathrm{f}$ type over lower frequency than that without one, and the larger was the change of cycle variance, the bigger was the degree of $1 / \mathrm{f}$ type.

Except the case when this fragrance is rather strong to a subject or given stress only by participating in the experiment, we suggested that a pleasant fragrance reduces stress. However, as it is considered this effect may occur independent of the taste of odor, it is necessary to be examined by not only a good odor but also a bad one.

\section{1. 諸訔}

アロマコロジ一の流行とともに，脳波や心拍な どの生体信号を指標として，香りによる心理・生 理効果を見る実験がさかんとなり，数多くの成果 が見られる様になった。

小杉等 2 ) が，脳波の周波数ゆらぎを用いた除痛 の研究結果を報告して以来, 吉田等 ${ }^{4}$ は, 脳波中 の $\alpha$ 波のリズムに着目し，快一不快の感情を $1 / \mathrm{f}$ ゆらぎを用いて説明している。

今回我々は，香りがストレス負荷後によ゙の様な

† 自221 横浜市神奈川区高島台 27-1；27-1 Takashimadai Kanagawa-ku, Yokahama, 221 Japan
影響を与元るかを見るために， $\alpha$ 波の周波数（周 期）ゆらぎを解析すると同時に，周期（半周期） の分散を比較検討してその效果を測定した。

\section{2。実験}

\section{1 被検者}

男 3 名女 1 名の計 4 名年眯（24 39歳）

\section{2 使用した香り}

当社で開発した環境用フレグランス（シトラス ミント系の香りD)

\section{3 ストレス}

4 析の数字の逆唱 (verbal task)

\section{4 脳波測定の手順}


安静時 (Rest) の脳波を記録した後，ストレス を2分かけ，香りを提示する場合，しない場合に ついてそれぞれ 5 分間ずつ脳波を記録したここの 際順序效果も考慮し, 測定終了時に香りの印象に ついて申告してもらった。

\section{5 䅦り0提示方法}

香料Dをミニポンプ (SIBATA, MP-30FT) によりマスク（新鋭工業 $\mathrm{KK}$ ，酸素自動人工呼吸 器）に $1 / / \mathrm{min} の$ 条件で送り込んだ。香料濃度 $3.8 \mathrm{mg} / \mathrm{l}$

\section{6 脳波計測}

脳波は頭皮上 5 ポイント（国際式10-20法に上 る $\mathrm{F}_{z}, \mathrm{C}_{3}, \mathrm{C}_{4}, \mathrm{Cz}_{z}, \mathrm{Oz}_{2}$ 上り 連結両耳梁基準電 極として単極導出し, 時定数 0.3 秒, 高域フィル ター $60 \mathrm{~Hz}$ でデータレコーダー（ソニー, $\mathrm{PC}-116)$ 飞記録した。尚, 測定は終始閉眼座位で行った。

\section{$2.7 \alpha$ 波の抽出と周期（半周期）の算出} 記録した背景脳波を $1 \mathrm{kHz}$ でA/D 変換し，゙゙ ジタルバンドパスフィルターにより， $8 \sim 13 \mathrm{~Hz}$ の周波数带域に相当する $\alpha$ 波を抽出し，電位を記 録した。次に基線をもとに、コンピュータ（日本 電気製 PC-9801RS）で各電位の積， $V_{n}{ }^{*} V_{n+1}$ が負または 0 になる点を求め, 前後の時間差を求 めて $\alpha$ 波の半周期（単位 $\mathrm{msec}$ ）在算出した。

\section{$2.8 \approx$ 波のゆらぎ解析}

各条件 (Rest, 香り提示, 香り不提示) での $\alpha$ 波の時間々隔4096ポイント（約 205 秒に相当）を 時系列に並べ波形を作り ${ }^{3)} ， 128$ ポイントを一区 間として32回の FFT 処理を行い，それぞれのパ ワースペクトルを加算平均して $\alpha$ 波の周波数ゆら ぎの RFTチャートを作成した。

またゆらゔの度合を見る為に，4096データに ついて分散（一区間 100 データ，5秒に相当，計 40 ポイント) を求めた。

\section{3. 結舆}

香りが少し強すぎると回答した被検者が1名い たが，香りの暸好性は高かった。

被検者全員について，Oz 数ゆらぎの FFTチャートを見ると，ストレス負 荷後香りを提示した場合（Stress-Perfume）は，
Table-1 香りの印象叶告結果

\begin{tabular}{|c|c|c|c|c|}
\hline 被 検 者 & 好 & 双 & 強さ & その他 \\
\hline S & 好 & き & 丁度よい & ほっとする \\
\hline U & & & 丁度よい & $\longrightarrow$ \\
\hline O & 好 & き & $\longrightarrow$ & - \\
\hline $\mathrm{N}$ & 好 & き & やや強い & 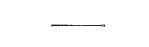 \\
\hline
\end{tabular}

ストレス負荷後香りを提示しない場合（StressRest）に比較して程度はま台まちであったが， $\alpha$

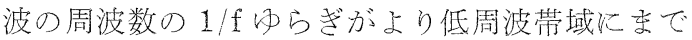

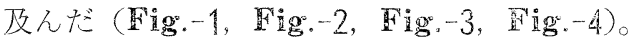

この事は，ゆらぎの状態が Restの状態に近付 いていることから，今回試験した香りはストレス 軽減に效果をもたらした場合があると考克られ た。

次に FFT チャート及び $\alpha$ 波の半周期データ 4096ポイントの分散值の変化を見ると

Fig.-1 の場合：FFT チャートで，(StressRest）の場合は，2Hz末で1/fゆらぎを 示している（2Hzより低周波数帯域では 白色化の傾向…即ち傾きが - 1 の $1 / \mathrm{f}$ 直 線からはずれてくる）のに対して，(Stress-Perfume) では $1 \mathrm{~Hz}$ とより低周波 数帯域にまで $1 / \mathrm{f}$ ゆらぎが持続してい る。

また，分散（ゆらぎの度合）が徐々に 大きくなり，Restの状態に近ついてい る事から，香り尤卡トレス軽減效果 が認められる。

Fig. -2 の場合：分散の変化を見ると (Stress) では，よくストレスが掛って扔り，スト レス解放後（Stress-Rest）でも直ちに， Rest 状態に戻っている様に見光るが， FFTチャートでは, (Stress-Psrfume) の場合， $0.8 \mathrm{~Hz}$ 本で1/fゆらぎが見られ るのに対して，(Stress-Rest)では1.5 Hz㐫たりから白色化の傾向泫る為, 香りの効果があったと判断した。

Fig:-3 の場合：Restの状態での分散值にバラ ツキが少なく、FFTチャートのRestで 
$\operatorname{LOG}(P)$

$(1 E+83)$
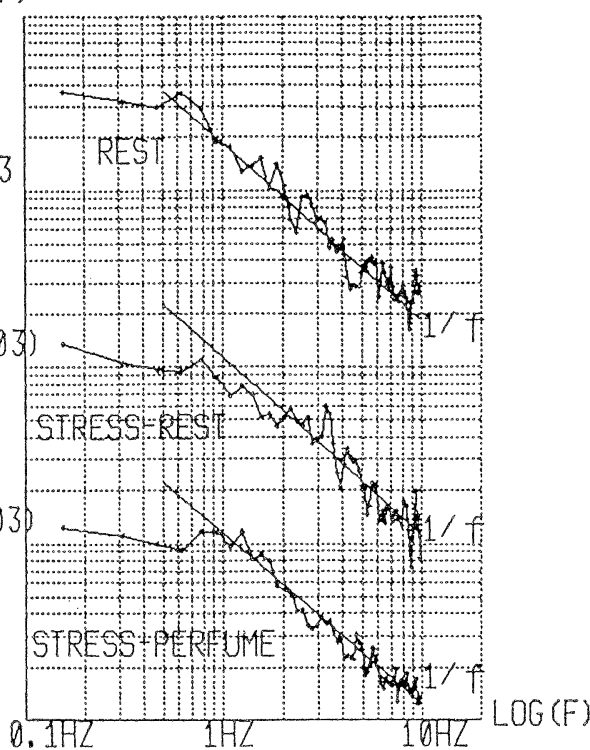

Fig.-1 被検者S36歳（男）の FFT チャート
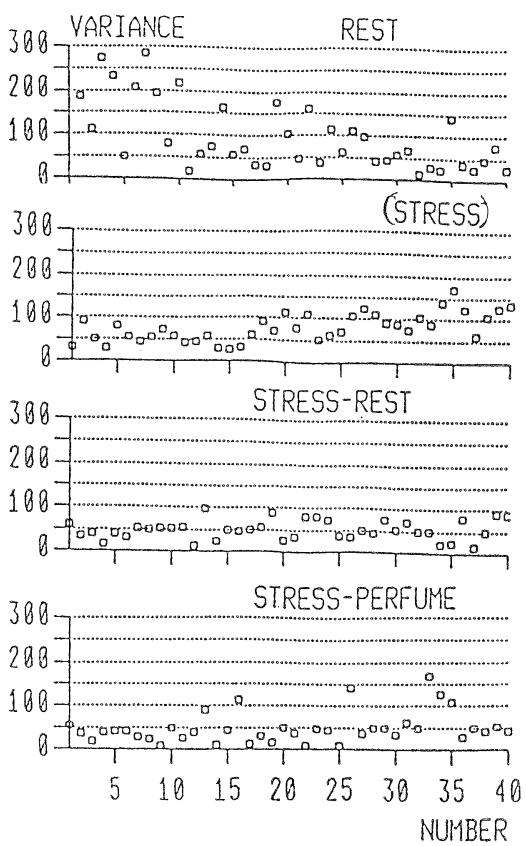

$(\mathrm{O} z)$ 及び $\alpha$ 波半周期の分散の変化

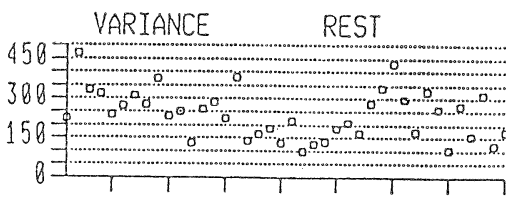

(STRESS)

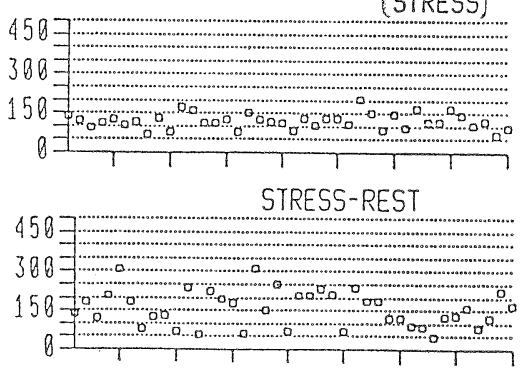

STRESS-PERFUME

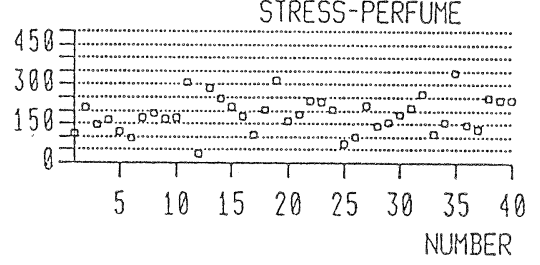

$(\mathrm{Oz})$ 及び $\alpha$ 波半周期の分散の変化

あることが分る。分散值の变化(StressPerfume) でも初めの25秒（分散で 5 ポ 

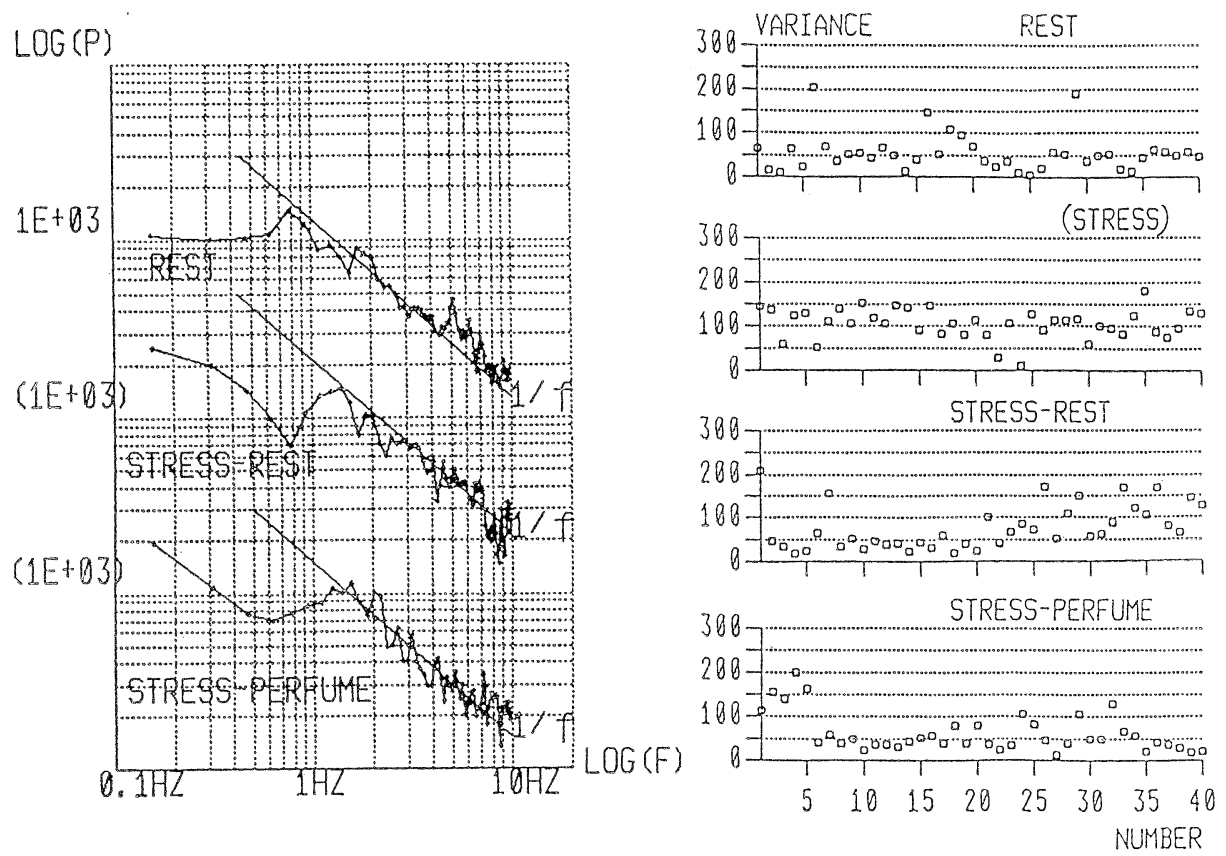

Fig.-3 被娭者O 24歳（女）のFFT チャート及び $\propto$ 波半夙期の分散の変化
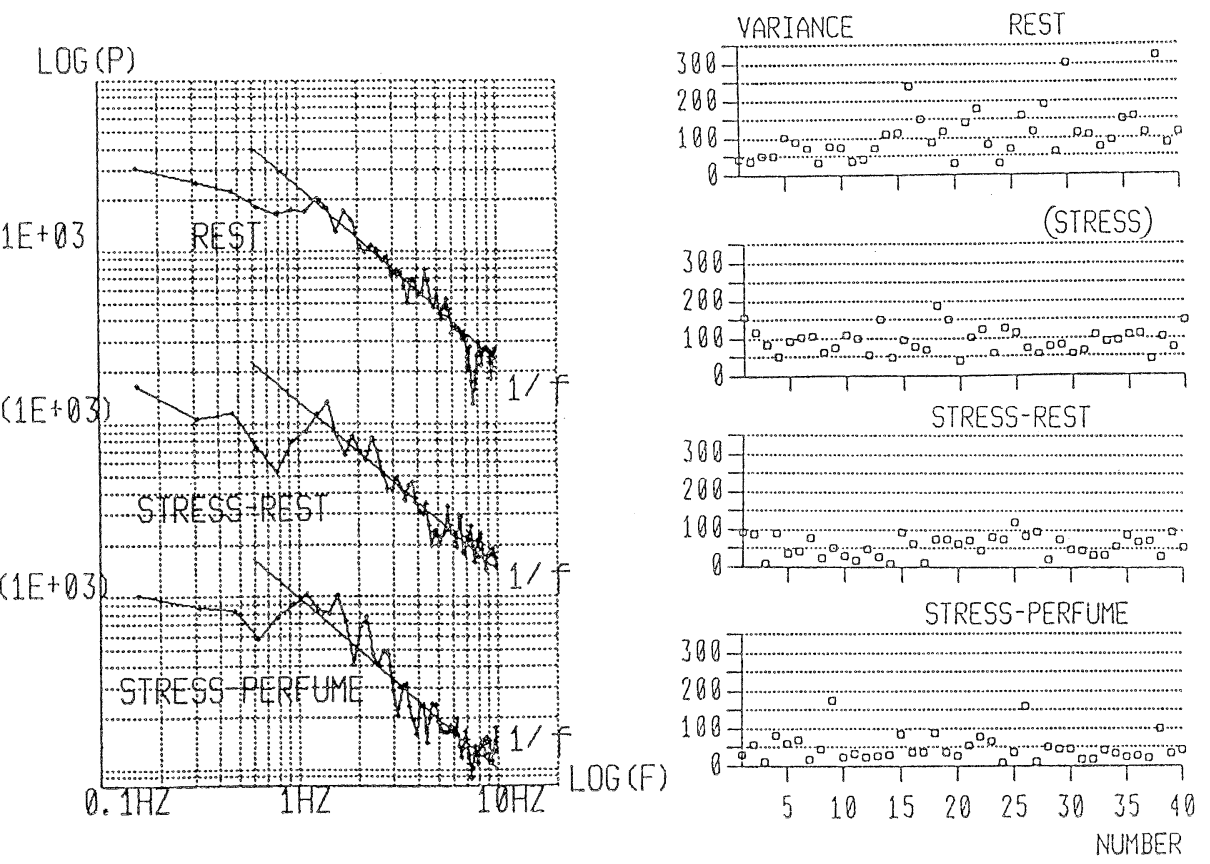

Fig。-4 被検者N 28歳（男）のFFT チャート及び $\alpha$ 波半周期の分散の変化

イントに相当）程はほっとした感じが見 受けられるが，なた，緊張状態になって
おり，香りによるリラックス效柴は見ら 机ない。 
被験者としてのストレス（脳波計測や その他の実験パラダイムに対しての）を 相当受けていたもの之思われる。

Fig.-4 の場合：分散の変化で, (Stress-Perfume）の場合，分散值が所々で大きくな って香りの效果が出はじめているが，全 体的に分散值が小さく，スペクトルのパ ワーレベルが低いところから依然として 緊張状態にある。

これは香りがやや強めに感じられてい ることに起因しているものと思われた。

以上のことが $\alpha$ 波の周波数ゆらざスペクトルと $\alpha$ 波の半周期（時間々隔）の分散の変化之の関連 性として考克られた。

尚, 分散の変化の中で (Stress) は, 2 回のス トレス負荷 (Stress-Rest, Stress-Perfume) による結果をつなぎ合わせたものである。

前頭部 $(\mathrm{Fz})$ では， $\alpha$ 波の出方が少ないため Restに於て，パワースペクトルは全体的に白色 化の傾向を示した。しかし暗算，香りを嗅ぐ等の タスクを与光ると $\alpha$ 波が前頭部 $(\mathrm{Fz})$ の方へシフ

\section{$\operatorname{LOG}(P)$}

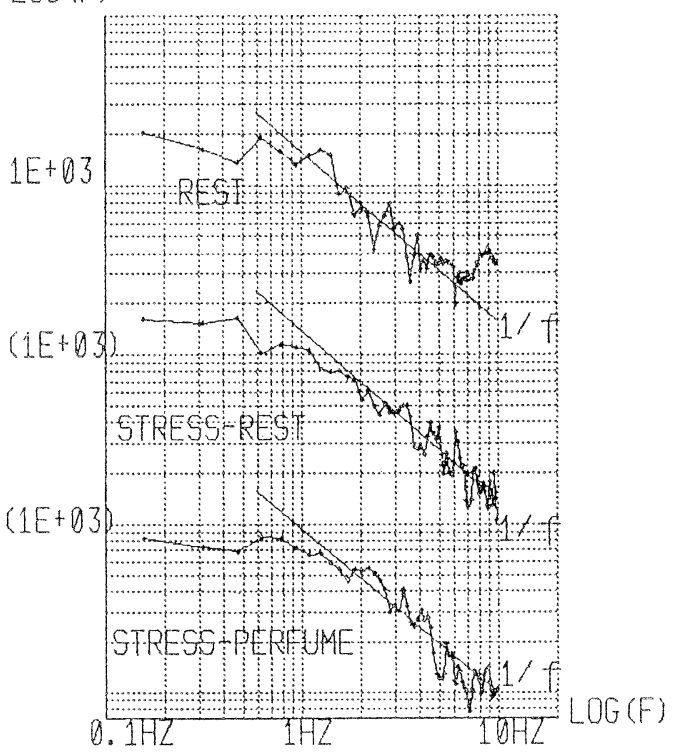

Fig.一五被検者 Sの FFT チャート (Fz)
トする事が示唆された（Fig:-5)。

また，中央領 $\mathrm{C}_{3}, \mathrm{C}_{4}, \mathrm{C}_{2}$ については， $\mathrm{Oz}$ と $\mathrm{FZ}$ の中間的な挙動を示した。

ストレス学か外た後に，香りを提示するしない の順序効果については例数が少ないために差を見 る事が出来なかったが，(Stress）の分散の変化 が少ない（ストレスのかかり方に差がない），即 ら暗算に対する慣れの効果がないため, 順序效果 は，この実験に関する限り無視出来るものと考克 られた。（香りを先湟示, Ffg.-1 と Fig。-3, 香 りを後に提示, Fig.-2之Fig。-4)

\section{4. 考察}

$\alpha$ 波の出やすい後頭部 $(\mathrm{O} z)$ の結果から, 香り がやや強めであったり，また実験に参画すること 自体にストレスを受けている様な場合を除いて は，ストレス負荷後，香りを提示した場合は，提 示しない場合に比較して, 早く $1 / \mathrm{f}$ ゆらぎの状態 に戻ることが見出され，被験者 4 例の少ないデー タではあるが，この実験に関する限り好ましい香 りは，暗算等による軽いストレスの軽減に効果が ある事が分った。

しかし，この効果が，香りの詣好性とは無関係 に好をしくない香りでも起る可能性がないと断言 出来ないため, 今回使用した香りの香り, 好末し くない香り等についても試験して見る必要がある と思われた。

謝辞 $1 / \mathrm{f}$ ゆらざの解析にあたって, 種々愁切な御 指導を賜り委した東京工業大学武者利光教授に対し, 深く感謝の意を表します。

\section{参考文献}

1）武者利光，ゆらぎの世界，Blue Backs (1980)

2) 小杉幸夫等, 電気通信学会技術研究報告 MBE 80 $59,33-40$ (1980)

3）鈴木良次他。生体信号, コロナ社（1981）

4）吉田倫幸，感情の生理計測，(人間老計万，'89製 科研講演会試料）

5）日野幹雄, スペクトル解析, 朝倉畫店 (1977) (1991年9月5日受理) 